\title{
Notes on the Indian wax scale, Ceroplastes ceriferus (Fabricius), from Korea (Hemiptera: Coccidae)
}

\author{
Yong-Hyun Lee, Wu San-an ${ }^{1}$ and Soo-Jung Suh*
}

Animal, Plant and Fisheries Quarantine and Inspection Agency, Busan 600-016, Korea

${ }^{1}$ The Key Laboratory for Silviculture \& Conservation of Ministry of Education, Beijing Forestry University, Beijing 100083, China

\section{한국산 뿔밀깍지벌리에 대한 정리 (노린재목, 밀깍지벌리과)}

\author{
이용현 · Wu San-an' · 서수정* \\ 농림수산검역검사본부 영남지역본부, '북경임업대학
}

\begin{abstract}
The Indian wax scale, Ceroplastes ceriferus (Fabricius) is redescribed so that it can be distinguished from Ceroplastes pseudoceriferus Green, which it most nearly resembles and has been confused with in Korea. A dichotomous key, photographs, and DNA barcode information are also presented for identifying three Ceroplastes species from Korea.
\end{abstract}

Key words: Ceroplastes ceriferus, redescription, key, Korea

초 록: 뿔밀깍지벌레(Ceroplastes ceriferus (Fabricius))는 형태적으로 유사한 C. pseudoceriferus Green과 혼동되어 동정되었으며, 이에 뿔밀깍지 벌레에 대한 형태적 특징을 재기재하였다. 이와 더불어 한국산 밀깍지벌레屬의 3 종을 동정하기 위한 검색표, 사진 및 DNA바코드 정보도 함께 제공 하였다.

검색어: 뿔밀깍지벌레, 재기재, 검색표, 한국

The genus Ceroplastes Gray are soft scale insects which have a characteristic thick wax test that covers the body of the adult female. These are most abundant in tropical and subtropical areas, but are known from all zoogeographic regions. Currently the genus contains approximately 139 species which have been reported worldwide (Ben-Dov et al., 2012). In Korea, three species, C.japonicus Green, $C$. pseudoceriferus Green, and $C$. rubens Maskell, have been previously documented (Paik, 1978; Paik, 2000; Lee, 2010).

The first record of the Indian wax scale in Korea was confirmed in 1930 by Machida and Aoyama. This species was considered to be a pest of persimmon, apple, pear, and cherry trees by Kanda (1941). In addition, it was listed as a serious pest

\footnotetext{
*Comesponding author: suhsj97@korea.kr

Received March 20 2012; Revised April 92012

Accepted April 192012
}

of Citrus plants in Jejudo, Korea (Paik, 1958), however, the name of the author of the species was incorrectly cited as Anderson in his paper. In the check list of insects from Korea, $C$. ceriferus was recorded under its common name, the Indian wax scale (Kwon et al., 1994).

However, it has been cited as Ceroplastes pseudoceriferus Green in recently published literatures (Paik, 1978, 1986; Paik, 2000; Han et al., 2002; Kwon and Han, 2003; Kwon et al., 2005; Lee, 2010). In the illustrated flora and fauna of Korea published by Paik (1978), the illustration of what was labeled as Ceroplastes pseudoceriferus Green, probably represents a misidentification of $C$. ceriferus. Recently we carefully reexamined some specimens collected during the 1970's that had been identified as $C$. pseudoceriferus based upon his book through comparing them to specimens of $C$. ceriferus deposited at the Florida State Collection of Arthropods; however we determined 
that all of them were actually $C$. ceriferus. Therefore, we consider the species Paik (2000) documented as C. pseudoceriferus to be a misidentification of C. ceriferus (Fabricius). In addition, $C$. ceriferus was misidentified as $C$. pseudoceriferus by Kwon and Han (2003) and Kwon et al. (2005), and the mention of $C$. pseudoceriferus in the checklist of Korean insects (Lee, 2010), probably represents a misidentification of $C$. ceriferus.

In Korea, the Indian wax scale, $C$. ceriferus has been confused with $C$. pseudoceriferus. The purpose of this paper is 1) to redescribe $C$. ceriferus so that it can be compared with $C$. pseudoceriferus which is not known to occur in Korea, 2) to provide an identification key to Korean Ceroplastes species and photographs of their major characters, and 3 ) to show a genetic evidence to support the existence of two species, $C$. ceriferus and C. pseudoceriferus.

\section{Materials and Methods}

\section{Morphological methods}

Terminology for morphological structures used in this paper is that of Gimpel et al. (1974). Photographs were taken using AxioCam MRc camera through ZEISS Axio Imager M2 Microscope and a LEICA M165C microscope with Delta pix camera. All specimens for accurate identification were mounted on slide and are deposited in the Collection of Yeongnam Regional Office, Animal, Plant and Fisheries Quarantine and Inspection Agency (QIA) in Busan, Korea. An asterisk(*) is used to indicate a new host record. Abbreviations are given as follows; GG: Gyeonggido; GB: Gyeongsangbukdo; GN: Gyeongsangnamdo; JB: Jeollabukdo; JN: Jeollanamdo; JJ: Jejudo.

\section{Molecular methods}

The collection information of Ceroplastes species are as follows (Table 1). With respect to the Korean three Ceroplastes species, the primers (Fwd_seq: CCTTCAACTAATCA TAAAAATATYAG, Rev_seq: TAAACTTCTGGATGTCCAAAAAATCA) that were used to amplify a $658 \mathrm{bp}$ fragment of the mitochondrial cytochrome $c$ oxidase subunit I gene (COI), for scale insects were designed by Park et al. (2010). All DNA was extracted from either dried or ethanol-fixed samples using a standard Glass Fibre extraction protocol (Ivanova et al., 2006). PCR thermocycling was done under the following conditions: $2 \mathrm{~min}$ at $95 \mathrm{C} ; 5$ cycles of $40 \mathrm{sec}$ at $94 \mathrm{C}, 40 \mathrm{sec}$ at $45 \mathrm{C}, 70 \mathrm{sec}$ at $72 \mathrm{C}$; 40 cycles of $40 \mathrm{sec}$ at $94 \mathrm{C}, 40 \mathrm{sec}$ at $51 \mathrm{C}, 70 \mathrm{sec}$ at $72 \mathrm{C} ; 5 \mathrm{~min}$ at $72 \mathrm{C}$; held at $4 \mathrm{C}$. DNA sequences of specimens of $C$. pseudoceriferus from China were provided by $\mathrm{Wu}$ and all analyses were conducted at Beijing Forestry University. Sequences were aligned in the ClustalW2 (ver. 2.1). Also, Neighbour-joining analysis, implemented in MEGA (ver. 2.1), was employed to show a relationship of three species of Ceroplastes from Korea, including C. pseudoceriferus from China.

\section{Results and Discussion}

\section{Description}

\section{Ceroplastes ceriferus (Fabricius), 1798 뿔밀깍지벌레}

Coccus ceriferus Fabricius, 1798: 546.

Field Characters. Body covered by thick white (young female) to pinkish white (old female) wet wax, convex, circular or irregular in outline, with an anteriorly projecting horn. Plates

Table 1. Collection details of Ceroplastes species used in the molecular analyses

\begin{tabular}{ll}
\hline \multicolumn{1}{c}{ Species } & \multicolumn{1}{c}{ Locality, number of samples, date, collector, and host } \\
\hline Ceroplastes ceriferus & Daedong-myeon, Gimhae (GN), 4 specimens, 27-ix-2005, S.J. Suh, on Camellia japonica \\
\cline { 2 - 3 } & Jungang-dong, Busan (GN), 3 specimens, 6-i-2012, S.J. Suh, on Camellia japonica \\
\hline & Jungang-dong, Busan (GN), 3 specimens, 6-i-2012, S.J. Suh, on Rhododendron indicum \\
\hline Ceroplastes japonicus & Jinhae (GN), 4 specimens, 8-v-2008, S.J. Suh, on Diospyros kaki \\
& Jungang-dong, Busan (GN), 3 specimens, 29-xii-2011, S.J. Suh, on Camellia japonica \\
\hline Ceroplastes pseudoceriferus & Yunnan, Kunming, China, 1 specimen, 17-ix-2011, Ying-jie Zhang, on Buxus megistophylla \\
\hline Ceroplastes rubens & Yeon-dong, Jeju (JJ), 2 specimens, 16-v-2006, S.J. Suh, on Citrus sp. \\
& Jungang-dong, Busan (GN), 4 specimens, 10-i-2012, S.J. Suh, on Camellia japonica \\
\hline
\end{tabular}


visible only on older females, without nuclei. Wax bands near both spiracles, anterior bands directed dorsally. Dry wax with filaments as follows: cephalic filament trifurcate; anterolateral and mediolateral simple; posterolateral bifurcate; caudal simple (Hamon and Williams, 1984).

Slide-mounted Characters. Dorsum: Without a mediodorsal clear area and with cephalic and posterolateral clear areas divided; dorsal setae predominantly cylindrical with rounded apices; with 1 ventral and 4 dorsal seta on each anal plate; with about 54 stigmatic setae laterad of each stigmatic furrow which are bullet-shaped to lanceolate, with pointed apices; with 1 dorsal submarginal band of filamentous ducts. Venter: Membranous with many cruciform pores; 1 ventral submarginal band of filamentous ducts; multilocular pores present on all abdominal segments and normally present near each coxa; with appendages unusually short, legs about 261 um long and antennae about 180 um long, legs without tibiotarsal scleroses, with unequal claw digitules; antennae 6-segmented (Gimpel et al., 1974; Kawai, 1980).

Material examined. Korea. GG: Opo-ri, Gwangju, 4 specimens, on Zizyphus jujuba (Rhamnaceae), 16-vii-1998 (I.T. Park); Incheon, 17 specimens, on ${ }^{*}$ Acer palmatum (Aceraceae), 1-viii1999; Seonhak-dong, Incheon, 2 specimens, on ${ }^{*}$ Rhododendron schlippenbachii (Ericaceae), 8-iii-2001 (H.J. Lee); Suwon, 5 specimens, on Camellia japonica (Theaceae), 27-ix-2005 (S.J. Suh); Anyang, 5 specimens, on Euonymus japonicus (Celastraceae), 1-i-2006 (S.J. Suh); Mampo-dong, Suwon, 3 specimens, on "Rhapis excelsa (Arecaceae), 29-ix-2006 (S.J. Suh); same data, except for on Zizyphus jujuba (Rhamnaceae). GB: Sangyeokdong, Daegu, 10 specimens, on ${ }^{*}$ Acer palmatum (Aceraceae), 18-iv-2009 (S.J. Suh). GN: Jungang-dong, Busan, 16 specimens, on ${ }^{*}$ Rhododendron indicum (Ericaceae), 10-x-2001 (Y.H. Lee); Daedong-myeon, Gimhae, 4 specimens, on Camellia japonica (Theaceae), 5-ix-2005 (S.J. Suh); same data, except for 27-ix2005; Choryang-dong, Busan, 9 specimens, on Pyracantha sp. (Rosaceae), 29-ix-2006 (S.J. Suh); Uponeup, Changwon, 1 specimen, on ${ }^{*}$ Robinia pseudoacacia (Fabaceae), 25-vi-2008 (S.W. Park); Oedo, 2 specimens, on Rhododendron indicum (Ericaceae), 6-xi-2008 (S.J. Suh); Danmok-ri, Jinju, 5 specimens, unknown plant, 10-i-2011 (S.J. Suh); Jungang-dong, Busan, 3 specimens, on Camellia japonica (Theaceae), 6-i-2012 (S.J. Suh); same data, except for on Rhododendron indicum (Eri- caceae). JB: Jeonju-arboretum, 1 specimen, unknown plant, 16-iii-2006 (S.J. Suh); Buan-gun, 2 specimens, Euonymus japonicus (Celastraceae), 17-iii-2006 (S.J. Suh). JN: Mokpo, 12 specimens, on Rhododendron sp. (Ericaceae), 10-v-2007 (S.J. Suh); Wando-arboretum, 1 specimen, on "Zanthoxylum planispinum (Rutaceae), 18-vi-2008 (S.J. Suh). JJ: Wolpyeong-dong, Seogwipo, 4 specimens, on Citrus unshiu (Rutaceae), 21-iii-1998 (S.M. Oh); Jeju, 1 specimen, on Morus alba (Moraceae), 11-v-2006 (S.Y. Gim).

Hosts. Polyphagous (fifteen plant families) (Ben-Dov et al., 2012).

Distribution. Palaearctic: Korea; China; Japan; Italy; United Kingdom; Canary Islands. Oriental: China; Hong Kong; Indonesia; Cambodia; Malaysia; Philippines; Ryukyu Islands; Sri Lanka; Taiwan; Thailand; Vietnam. Australasian: Australia; Christmas Island; Cook Islands; Fiji; Guam; Hawaiian Islands; New Caledonia; New Zealand; Palau; Papua New Guinea; Tonga; Vanuatu. Afrotropical: Tanzania; Uganda. Nearctic: Mexico; United States of America. Neotropical: Brazil; Chile; Guadeloupe; Jamaica; Panama; Puerto Rico \& Vieques Island; U.S. Virgin Islands (Ben-Dov et al., 2012).

Economic importance. This species is especially an economic pest of ornamental and garden plants growing in urban. It secretes large quantities of honeydew which provides a medium for sooty mold. The sooty mold may become so dense that it interferes with photosynthesis (Hamon and Williams, 1984).

Remarks. We determined that the 143 specimens labeled as $C$. pseudoceriferus, deposited at the National Academy of Agricultural Science, Korea were actually C. ceriferus.

\section{Identification tools}

The dichotomous keys of wax tests and slide mounted characters are provided to distinguish adult females of Ceroplastes species from Korea.

\section{Key to the wax tests of adult females Ceroplastes in Korea}

1. Wax test (or cover) white to pinkish white, round to oval or irregular in dorsal view, with an anteriorly projecting horn (Fig. 1A) Ceroplastes ceriferus (Fabricius) 
1b. Wax cover, beige to grayish white or pink to reddish, pentagonal to hexagonal in dorsal view, without horn (Fig. $1 \mathrm{D}, \mathrm{G})$ .. 2

2b. Wax cover pentagonal in dorsal view, pink to reddish (Fig. 1G) Ceroplastes rubens Maskell

2b. Wax cover hexagonal in dorsal view, grayish white (Fig. 1D) Ceroplastes japonicus Green

Key to slide mounted adult females Ceroplastes in Korea

1. Mediodorsal clear area present; ventral tubular ducts absent; legs reduced (Fig. 1H)

\section{Ceroplastes rubens Maskell}

1b. Mediodorsal clear area absent; ventral tubular ducts present; legs well developed (Fig. 1B, E) 2

2. Stigmatic setae arranged in 6 irregular rows present discontinuously between anterior and posterior stigmatic furrows (Fig. 1C)

Ceroplastes ceriferus (Fabricius)

2b. Stigmatic setae arranged in 3 irregular rows present continuously between anterior and posterior stigmatic furrows (Fig. 1F)

Ceroplastes japonicus Green

We consider that C. pseudoceriferus, does not exist in Korea, and that previous records of this species in Korea represent a

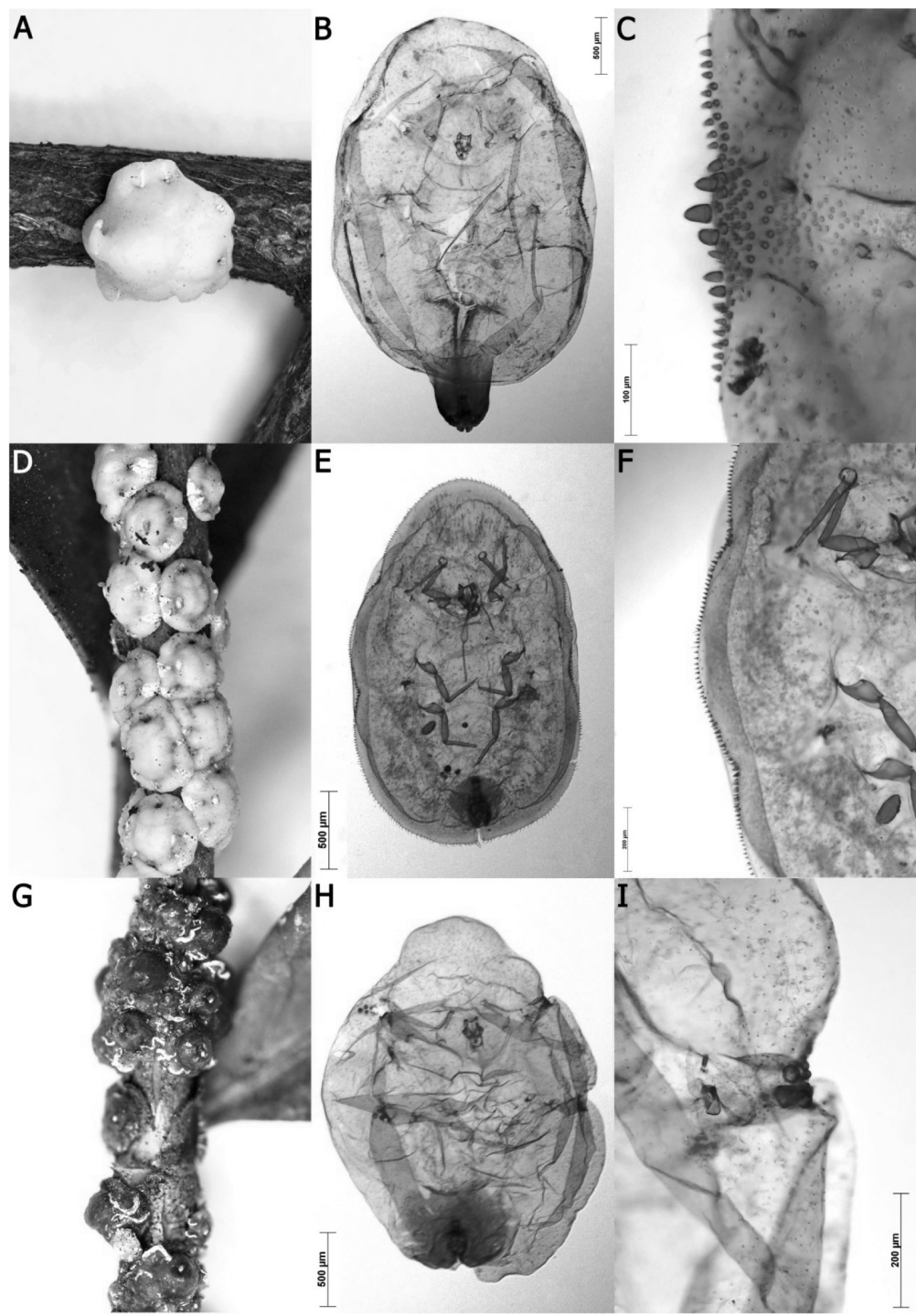

Fig. 1. A-B) Ceroplastes ceriferus, adult female; C) C. ceriferus, anterior stigmatic setae; D-E) C. japonicus, adult female; F) C. japonicus, setae between anterior and posterior stigmatic furrow; G-H) C. rubens, adult female; I) C. rubens, anterior stigmatic setae. 


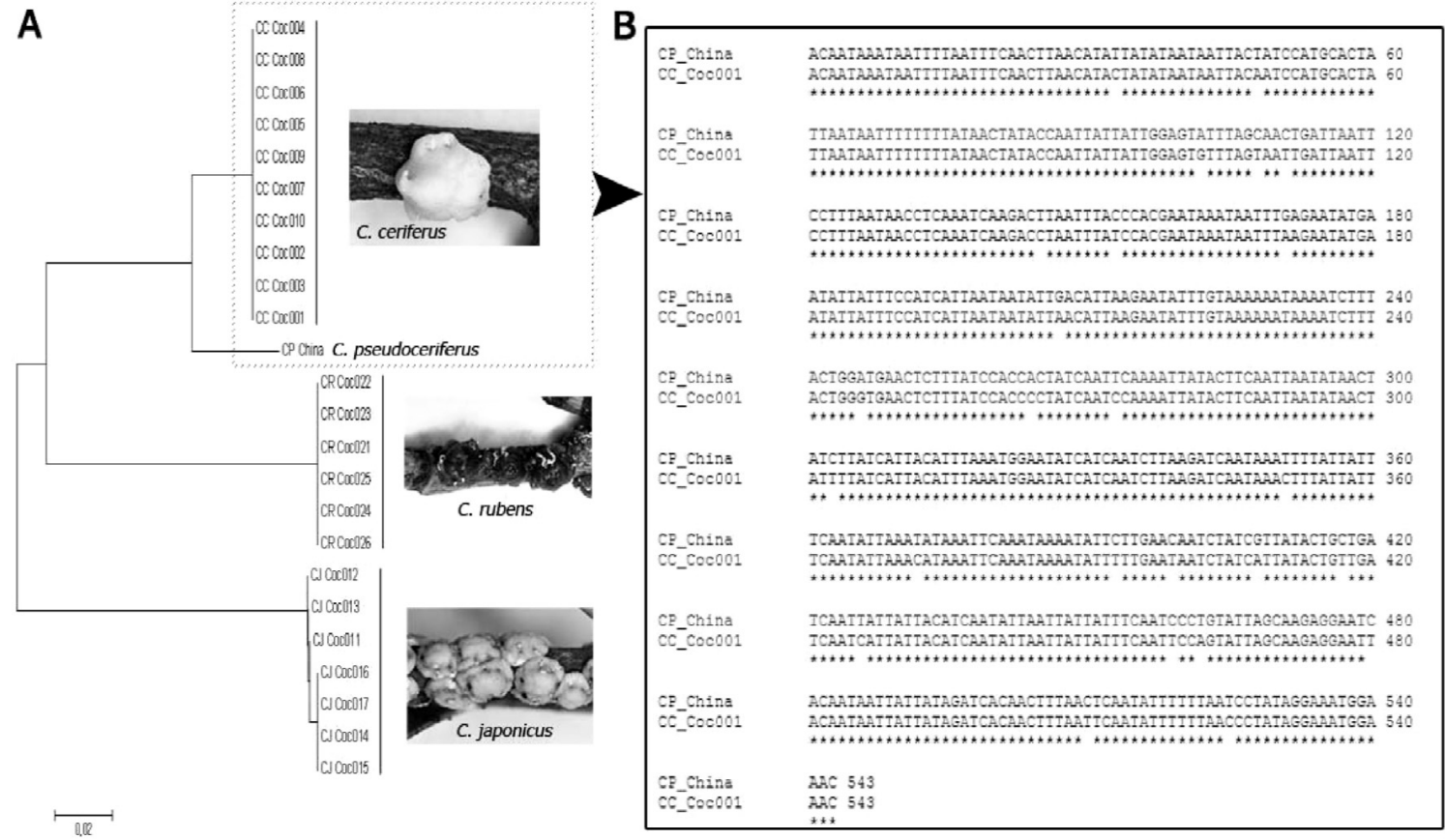

Fig. 2. A) COI neighbor-joining tree of Ceroplastes species from Korea; B) Alignment of COI barcode region from C. ceriferus (CC_Coc001) and C. pseudoceriferus (CP_China).

misidentification of $C$. ceriferus. C. pseudoceriferus most nearly resembles $C$. ceriferus, but can be distinguished from the latter species by following characters: $C$. pseudoceriferus has about 40 marginal bristle-shaped setae between the anterior stigmatic furrows; about 10 such setae between each anterior and posterior stigmatic furrow; and about 130 stigmatic setae laterad of each stigmatic furrow. Whereas, C. ceriferus possesses about 10 marginal bristle-shaped setae between the anterior stigmatic furrows; about 3 such setae between each anterior and posterior stigmatic furrow; and about 54 stigmatic setae laterad of each stigmatic furrow (Gimpel et al., 1974; Tang, 1991).

In addition, we used the 543 base pair DNA barcode region of the COI for the discrimination of allied species, C. ceriferus and C. pseudoceriferus. The alignment of their sequences showed 25 base-pair mismatch positions and the COI divergence was $4.6 \%$ (Fig. 2). COI-based sequences were indicative of different species, which also provided genetic evidence to support the separation of $C$. ceriferus from $C$. pseudoceriferus based on morphological differences.

The proper evaluation of the potential threat of a Ceroplastes species intercepted on imported plants and the determination of the appropriate response or action that needs to be taken, require the knowledge of which species of Ceroplastes are already known to occur in Korea. We confirmed that three species, $C$. ceriferus (Fabricius), C.japonicus Green, and C. rubens Maskell, occur in Korea, through carefully re-examination of previously collected specimens and recent survey. The morphology and DNA-based approach can make accurate identification possible. Morphological identification is primarily based on characteristics of the adult female. With the use of DNA, it is now possible to identify some life stages such as eggs and young larvae of Ceroplastes species that were previously not identifiable to species level.

\section{Acknowledgments}

We would like to thank Dr. Greg Evans (USDA/Animal and Plant Health Inspection Service, USA) for his useful editorial contributions to this manuscript. We also thank Drs. Doo-Sang Park (Biological Resource Center, Korea Research Institute of Bioscience \& Biotechnology, Daejeon) and Deuk-Soo Choi (QIA) for helping DNA analyses. Funding for this project came from QIA. 


\section{Literature Cited}

Ben-Dov, Y., D.R. Miller and G.A.P. Gibson. 2012. ScaleNet (webpage) http:// www.sel.barc.usda.gov/scalenet/scalenet.htm. Accessed 5 March 2012.

Fabricius, J.C. 1798. Supplementum Entomologiae Systematicae. 472 pp. Proft and Storch, Hafniae.

Gimpel, W.F., D.R. Miller and J.A. Davidson. 1974. A systematic revision of the wax scales, genus Ceroplastes, in the United States (Homoptera; Coccoidea; Coccidae). University of Maryland, Agricultural Experiment Station, Miscellaneous Publication 841: 1-85.

Hamon, A.B. and M.L. Williams. 1984. The soft scale insects of Florida (Homoptera: Coccoidea: Coccidae). 194 pp. Florida Department of Agriculture and Consumer Services, Division of Plant Industry, Gainesville.

Han, M.J., S.H. Lee, J.Y. Choi, G.S.Lee, G.M. Kwon, Y.M. Park, J.G. Yoo, D.R. Choi and H.G. Goh. 2002. Scale insects on horticulture crops. $121 \mathrm{pp}$. National Institute of Agricultural Science and Technology, Suwon.

Ivanova, N.V., J.R. deWaard and P.D.N. Hebert. 2006. An inexpensive, automation-friendly protocol for recovering highquality DNA. Molecular Ecology Notes. doi: 10.1111/j.14718286.2006.01428.x

Kanda, S. 1941. Studies on Coccidae from Corea. Insect World 45(12): 356-361.

Kawai, S. 1980. Scale insects of Japan in colors. 455 pp. National Agricultural Education Association, Tokyo.

Kwon, G.M. and M.J. Han. 2003. Scale insects (Sternorrhyncha) occurred on fruit trees in Korea. Kor. J. Appl. Entomol. 42(4): 279-288.

Kwon, G.M., M.J. Han and D.R. Choi. 2005. Scale insects (Sternorrhyncha) occurring on flowering plants in Korea. Kor. J. Appl. Entomol. 44(1): 51-59.

Kwon, Y.J., C.E. Lee, K.W. Lee and E.Y. Huh. 1994. Family Coccidae. pp. 111-112. In Check list of insects from Korea, ed. by H.S. Ryu. 744 pp. Kon-Kuk University press, Seoul.

Lee, Y.J. 2010. Family Coccidae. pp. 79-80. In Checklist of Korean insects, ed. by M.K. Paek, 598 pp. Nature and Ecology, Seoul.

Machida, S. and T. Aoyama. 1930. Pest insects of Korea, $2^{\text {nd }}$ vol. (In Japanese). 424 pp. Miyake Publishing Company, Busan.

Paik, J.C. 2000. Economic Insects of Korea 6, Homoptera (Coccinea). Insecta Koreana Suppl. 13. 193 pp. National Institute of Agricultural Science and Technology.

Paik, W.H. 1958. Citrus insect problems in Quelpart island. J. Appl. Zool. 1(1): 26-35.

Paik, W.H. 1978. Illustrated flora and fauna of Korea, vol. 22, Insecta (VI), Coccoidea. 481 pp. Samhwa Publishing Company, Seoul.

Paik, W.H. 1986. Coccidae. pp. 170-171. In A list of plant diseases, insect pests and weeds in Korea, ed. by Y.S. Jo. 633 pp. Niu Publishing Company, Seoul.

Park, D.S., S.J. Suh, H.W. Oh and P. DN Hebert. 2010. Recovery of the mitochondrial COI barcode region in diverse Hexapoda through tRNA-based primers. BMC Genomics 11: 423-430.

Tang, F.T. 1991. The Coccidae of China. 377 pp. Shanxi United Universities Press, Taiyuan, China. 